TITLE:

ON THE OCCURRENCE OF

CHAETOGNATHS IN THE TANSHUI RIVER ESTUARY OF NORTHERN TAIWAN (FORMOSA)

AUTHOR(S):

Liaw, Wen Kuang

CITATION:

Liaw, Wen Kuang. ON THE OCCURRENCE OF CHAETOGNATHS IN THE TANSHUI RIVER ESTUARY OF NORTHERN TAIWAN (FORMOSA). PUBLICATIONS OF THE SETO MARINE BIOLOGICAL LABORATORY 1967, 15(1): 5-18

ISSUE DATE:

1967-05-25

URL:

http://hdl.handle.net/2433/175457

RIGHT: 


\title{
ON THE OCCURRENCE OF CHAETOGNATHS IN THE TANSHUI RIVER ESTUARY OF NORTHERN TAIWAN (FORMOSA)
}

\author{
Wen Kuang LIAW \\ Department of Zoology, National Taiwan University
}

With Plate I, 9 Text-figures and 7 Tables

\begin{abstract}
Introduction
While chaetognaths are extensively studied in various parts of the world in connection with hydrography of the ocean (e.g. Bieri, 1959; Furuhashi, 1961; Pierce, 1958; Pierce \& Wass, 1962; Sund, 1959, etc.), they have been neglected from the coastal waters of Taiwan. So far as the author could ascertain there has been only one report (Ho, 1963) which deals with the seven species of chaetognaths from Keelung Harbor and around the Penghu Islands. These species are: Sagitta hexaptera, Sagitta enflata, Sagitta robusta, Sagitta bedoti, Sagitta serratodentata, Sagitta regularis and Sagitta neglecta. In addition, BIERI's report (1959) on the distribution of chaetognaths in the Pacific can be considered indirectly dealing with chaetognaths in the waters of Taiwan. From his distribution charts, 11 species among the 27 can be found to have their distributions in the waters surrounding Taiwan. Thus, if we take BIERI's data into account, 13 species of chaetognaths, i.e. S. enflata, S. ferox, S. hexaptera, S. pacifica, S. californica, S. robusta, S. pulchra, S. bedoti, S. regularis, S. serratodentata, S. neglecta, Pterosagitta draco and Krohnitta pacifica, may be found in the coastal waters of Taiwan. The purpose of this study is to see which of these species can be found invading the near shore and estuarine waters, and how they are related to some of the hydrographical features of these waters.
\end{abstract}

\section{Material and Method}

The material for the present study consists of more than 3,000 specimens of chaetognaths found in the plankton samples collected in March, 1964 and February, 1965 to May, 1966 (no collections made in January, 1966 and from March to June, 1965) in the Tanshui River Estuary. All collections were made by hauling the net horizontally one meter under the surface except those made in March, 1964 which were oblique hauls. The plankton net used in the collection had the following

Publ. Seto Mar. Biol. Lab., XV (1), 5-18, 1967. (Article 2) 
measurements: inner mouth diameter, $45 \mathrm{~cm}$; mesh size, pylen cloth \#60, 0.345 mm. The center of the mouth of the net was mounted with a flow meter (Rigosha, No. 404). Usually five collections were made on each trip at one to $1 \frac{1 / 2}{2}$ hour intervals to cover different tidal phases. Surface water temperatures were recorded at the time of every collection. In addition, water samples for salinity and dissolved oxygen determination were also taken at the time of each collection made in 1966.

Plankton samples were immediately fixed in formalin solution in the field by adding suitable amount of concentrated formalin. All plankton samples were examined under a binocular and chaetognaths were sorted out and preserved in $5 \%$ formalin solution. Some were preserved in Bouin solution, of which it was found later that Bouin solution caused the shrinkage of the fins in most cases and made identification difficult.

\section{General Hydrography of the Area Studied}

The estuary was divided into two sections in the study (Fig. 1). Upper section included the area between Chuwei and Kuantu, and lower section was the river

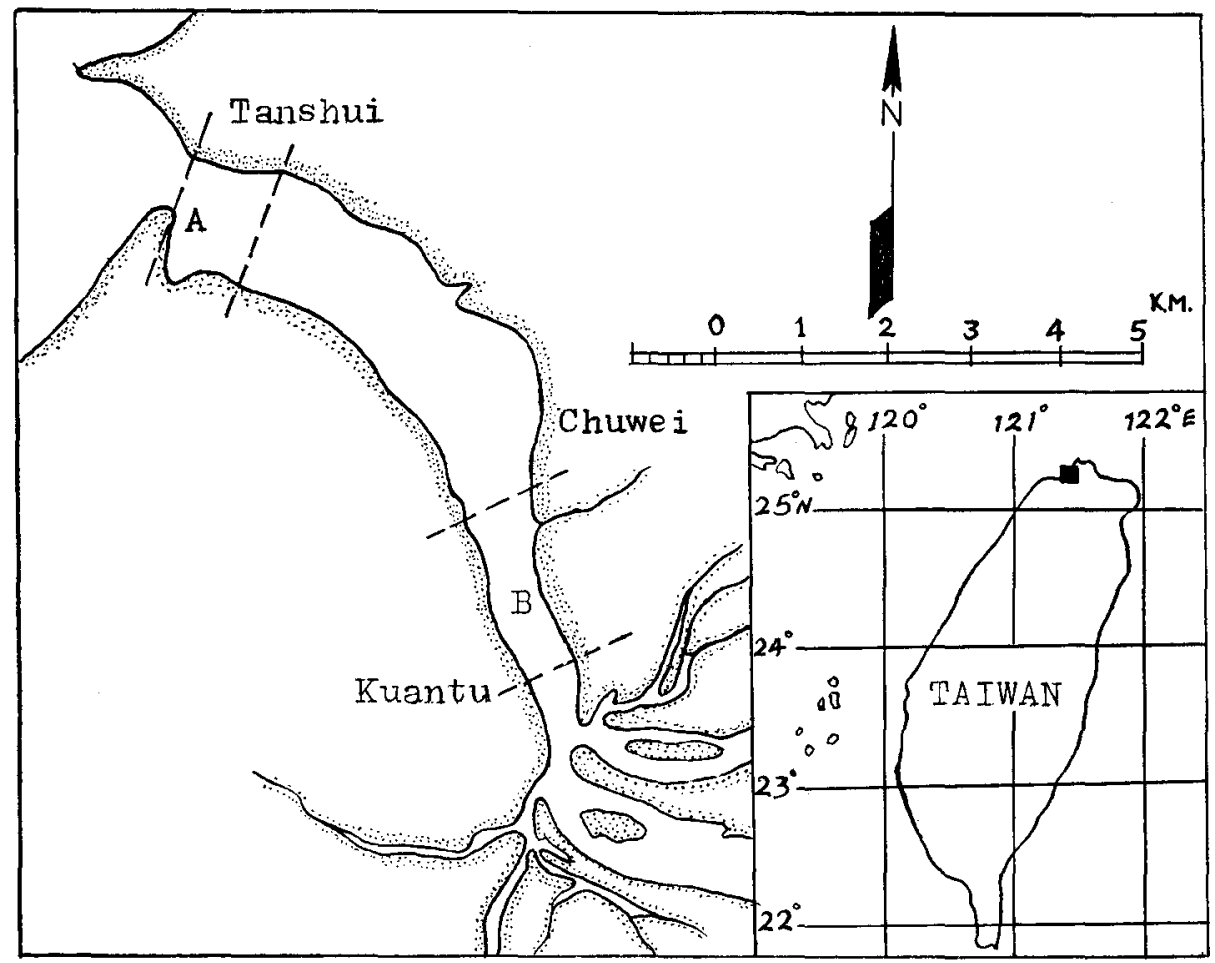

Fig. 1. Map of the Tanshui River Estuary showing the sampling sites: A, the lower estuary; B, the upper estuary. 
mouth at Tanshui. The characteristics of the bottom of these two sections were different; sandy at the lower section and muddy at the upper section.

Temperature: Comparison of temperatures taken in the upper estuary in recent years and the present data (Fig. 2) shows that the surface water temperature did not vary very much. The highest water temperature was found in July; about $29^{\circ} \mathrm{C}$ in $1962-64$, and $32^{\circ} \mathrm{C}$ in 1965 . The lowest water temperature was in January; about $13^{\circ} \mathrm{C}$ in $1962-64$, and $17.5^{\circ} \mathrm{C}$ in 1965 . Comparison of temperatures taken during various tidal phases shows little fluctuation.

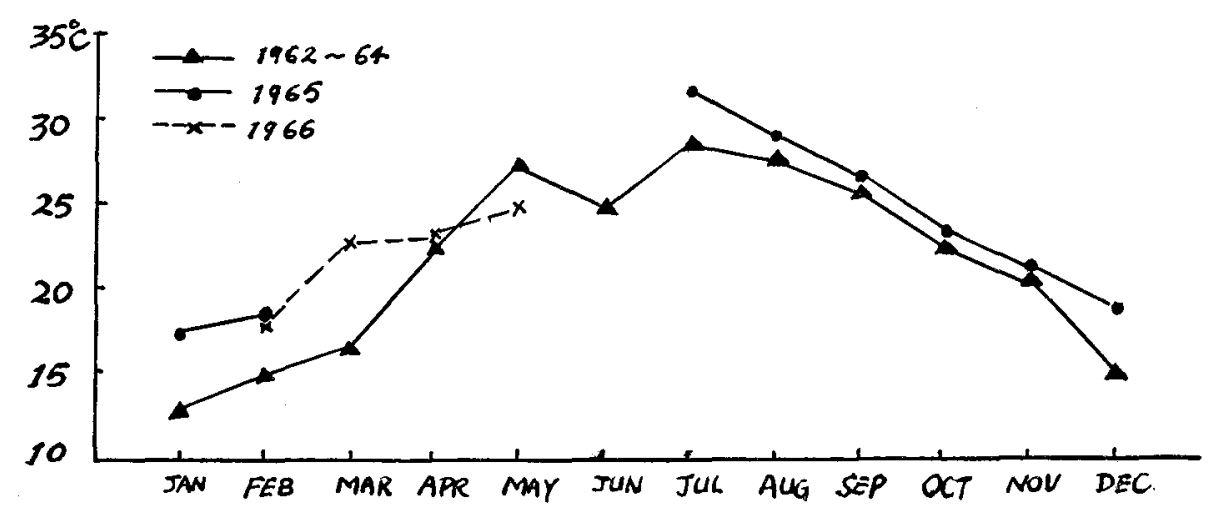

Fig. 2. Monthly average surface water temperatures of the upper Tanshui River Estuary.

Salinity: Salinities varied considerably with different tidal phases; highest during the flood tide and lowest during the ebb tide. The highest salinity encountered within the entire sampling period was $30.55 \%$ on May 28 . The mean salinity during the

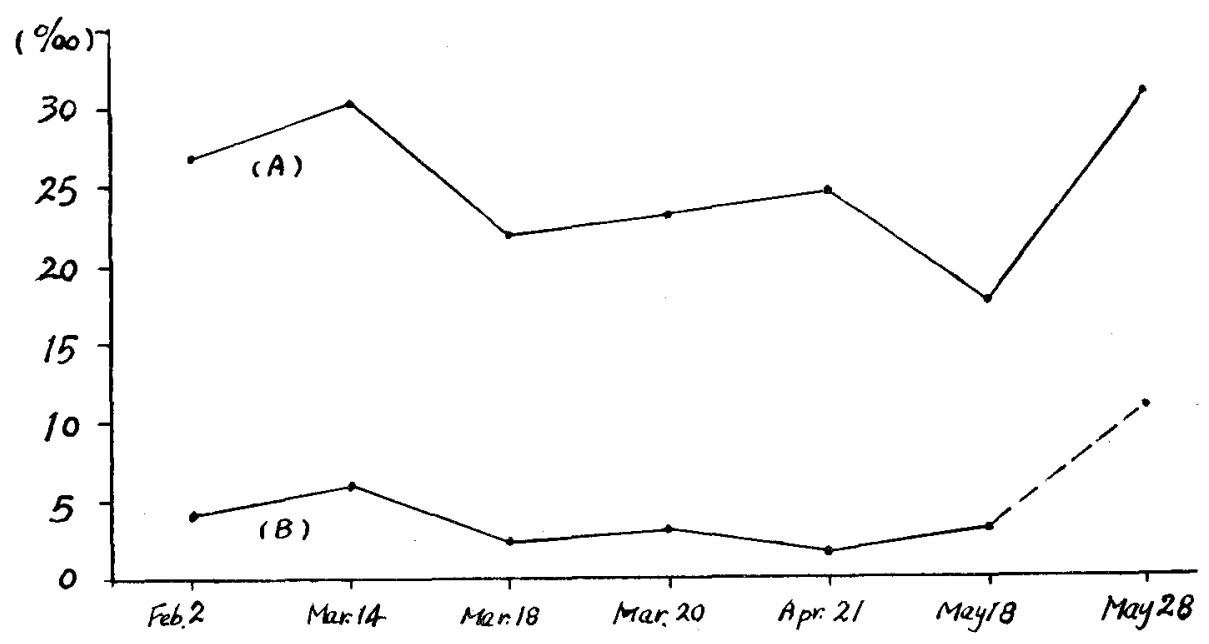

Fig. 3. Salinities measured at flood (curve A) and ebb (curve B) tides in the upper estuary during each cruise in 1966 (no measurement strictly at the ebb tide on May 28). 
flood tide in the upper estuary was $25.03 \%$. The salinities taken during the ebb tide were rather stable. They varied from 1.76 to $5.97 \%$ during the entire sampling period, with an average of $3.44 \%$ (Fig. 3).

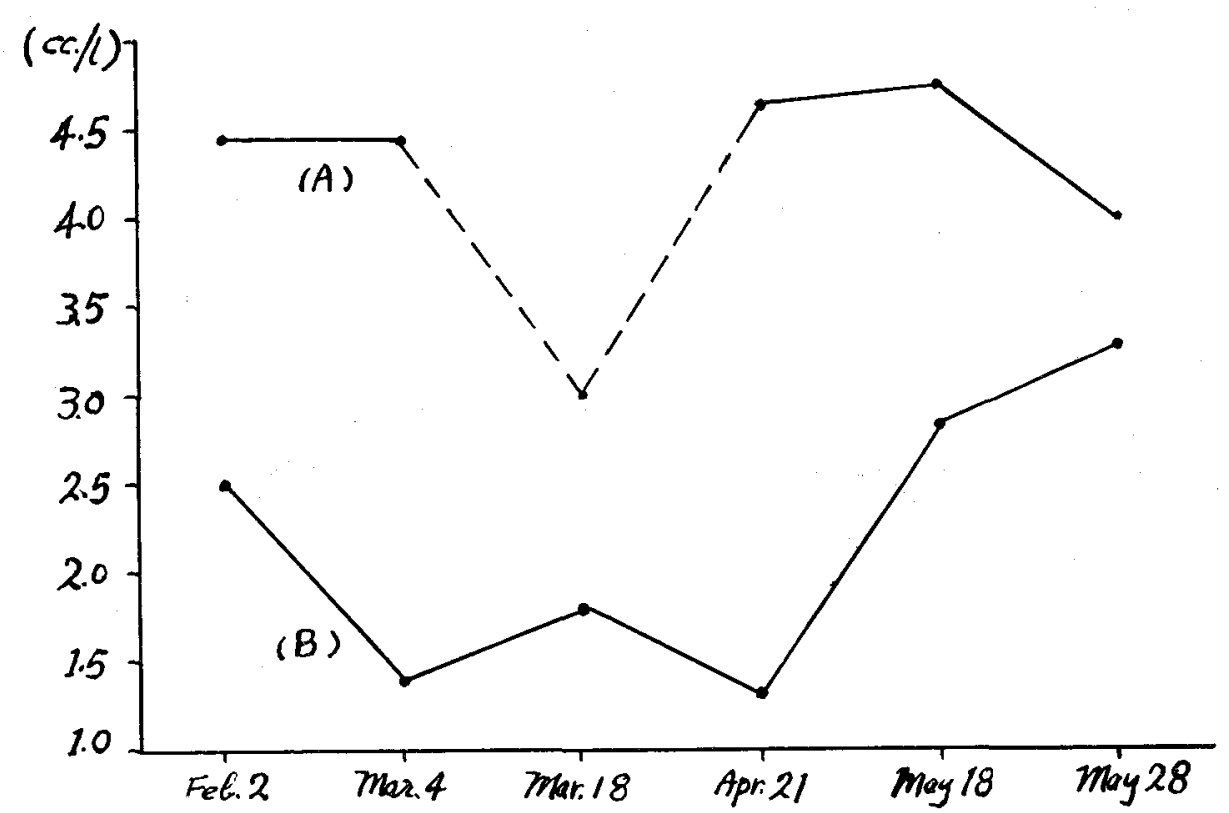

Fig. 4. Concentrations of dissolved oxygen measured at flood (curve A) and ebb (curve B) tides in the upper estuary during each cruise in 1966 (no measurement strictly at the flood tide on Mar. 18).

Dissolved Oxygen: The amount of dissolved oxygen also increased with the raising of water level. Figure 4 indicates the highest and the lowest amount of dissolved oxygen recorded on each cruise in 1966. It is clear that the oxygen dissolved during the flood tide was rather stable; ranged only from 4.40 to $4.76 \mathrm{cc} / \mathrm{l}$ with a mean of $4.54 \mathrm{cc} / 1$. On the contrary it fluctuated greatly during the ebb tide; ranged from 1.30 to $3.28 \mathrm{cc} / 1$ with a mean of $2.18 \mathrm{cc} / 1$.

\section{Occurrence of Chaetognaths}

Five species of chaetognaths, Sagitta bedoti, Sagitta enflata, Sagitta robusta, Krohnitta pacifica and Pterosagitta draco were identified in the material. These species were ascertained by close examination of dental formulae, measurements of the tail segment of many individuals (Tables 1 to 5 ), the shape and position of the corona ciliata (Fig. 5) and of the shape and position of the seminal vesicles (Pl. I) and ovaries if the specimen was mature enough. Among the five, $S$. bedoti was the most abundant species and $S$. enflata the second. The rest three species occurred only sparsely in the 
Table 1. Formulae of $S$. bedoti examined.

\begin{tabular}{|c|c|c|c|c|c|c|c|}
\hline Sp. No. & $\mid \begin{array}{c}* \text { Body length } \\
\text { in } \mathrm{mm}\end{array}$ & $\begin{array}{l}* \text { Tail segment } \\
\text { in \% }\end{array}$ & Hooks & $\begin{array}{c}\text { Anterior } \\
\text { teeth }\end{array}$ & $\begin{array}{l}\begin{array}{c}\text { Posterior } \\
\text { teeth }\end{array} \\
\end{array}$ & Ovaries & $\begin{array}{c}\text { Seminal } \\
\text { vesicles }\end{array}$ \\
\hline 1 & 3.30 & 28.57 & $8-8$ & $4-4$ & $9-9$ & - & - \\
\hline 2 & 3.96 & 27.08 & $9-9$ & $5-5$ & $10-10$ & - & 一 \\
\hline 3 & 3.96 & 27.08 & $8-8$ & $5-6$ & $10-10$ & - & - \\
\hline 4 & 4.29 & 25.00 & $7-7$ & $5-6$ & $9-10$ & - & - \\
\hline 5 & 4.95 & 25.00 & $8-8$ & $7-6$ & $11-11$ & - & - \\
\hline 6 & 5.94 & 23.61 & $9-9$ & $7-6$ & $15-15$ & - & - \\
\hline 7 & 6.60 & 22.50 & $7-7$ & $7-8$ & $13-14$ & - & - \\
\hline 8 & 6.60 & 25.00 & $8-8$ & $8-7$ & $16-17$ & + & - \\
\hline 9 & 6.93 & 23.81 & $8-8$ & $10-10$ & $18-18$ & + & - \\
\hline 10 & 7.26 & 27.27 & $7-7$ & $10-10$ & $19-20$ & + & + \\
\hline 11 & 7.92 & 25.00 & $8-8$ & $7-7$ & $14-13$ & - & - \\
\hline 12 & 9.57 & 20.69 & $7-7$ & $10-10$ & $18-18$ & + & + \\
\hline 13 & 12.54 & 21.05 & $7-7$ & $11-11$ & $19-19$ & + & - \\
\hline 14 & 14.52 & 22.73 & $7-7$ & $10-10$ & $18-18$ & $H$ & H \\
\hline 15 & 14.52 & 22.73 & $7-7$ & $11-11$ & $20-20$ & $H$ & Ht \\
\hline 16 & 15.18 & 21.74 & $7-7$ & $11-11$ & $19-19$ & H & H \\
\hline 17 & 15.18 & 23.91 & $7-7$ & $11-11$ & $21-21$ & $H$ & H \\
\hline 18 & 15.84 & 20.83 & $7-7$ & $10-10$ & $19-19$ & $H$ & $\mathrm{H}$ \\
\hline 19 & 15.84 & 20.83 & $7-7$ & $11-10$ & $18-19$ & H & H \\
\hline 20 & 19.14 & 24.14 & $7-7$ & $13-13$ & $26-26$ & Hit & $H$ \\
\hline
\end{tabular}

* Tail fin excluded. Maturity condition: - no trace of ovaries or seminal vesicles; + ovaries or seminal vesicles are just appearing, ovaries as short thin tubes; \# seminal vesicles conspicuous, ovaries also conspicuous with small round eggs reach the posterior end of anterior fins; H seminal vesicles discharging or discharged, ovaries with ripe round eggs reach the posterior end of anterior fins.

Table 2. Formulae of S. enflata examined.

\begin{tabular}{|c|c|c|c|c|c|c|c|}
\hline Sp. No. & $\begin{array}{c}* \begin{array}{c}\text { Body length } \\
\text { in } \mathrm{mm}\end{array} \\
\end{array}$ & $\begin{array}{c}{ }^{*} \text { Tail segment } \\
\text { in } \%\end{array}$ & Hooks & $\begin{array}{c}\text { Anterior } \\
\text { teeth }\end{array}$ & $\begin{array}{c}\text { Posterior } \\
\text { teeth }\end{array}$ & Ovaries & $\begin{array}{l}\text { Seminal } \\
\text { vesicles }\end{array}$ \\
\hline 1 & 4.62 & 21.43 & $10-10$ & $4-4$ & $4-5$ & - & - \\
\hline 2 & 4.62 & 21.43 & $10-10$ & $4-4$ & $5-5$ & - & - \\
\hline 3 & 4.62 & 17.86 & $10-10$ & $3-3$ & $5-5$ & - & - \\
\hline 4 & 5.94 & 16.67 & $9-9$ & $4-4$ & $4-4$ & - & - \\
\hline 5 & 9.57 & 15.52 & $9-9$ & $6-6$ & $13-13$ & + & - \\
\hline 6 & 10.89 & 18.18 & $10-10$ & $8-8$ & $12-12$ & H & H \\
\hline 7 & 11.22 & 15.44 & $10-10$ & $8-8$ & $13-13$ & + & - \\
\hline 8 & 11.55 & 15.71 & $10-10$ & $8-9$ & $12-12$ & H & + \\
\hline 9 & 11.88 & 15.28 & $10-10$ & $9-9$ & $12-12$ & H & + \\
\hline 10 & 12.54 & 15.79 & $10-10$ & $8-8$ & $12-12$ & H & H \\
\hline 11 & 13.86 & 15.48 & $10-10$ & $9-9$ & $14-14$ & \# & H \\
\hline 12 & 13.86 & 14.29 & $9-9$ & 8- 8 & $13-13$ & H & H \\
\hline 13 & 14.85 & 15.56 & $10-10$ & $9-9$ & $15-15$ & H & H \\
\hline 14 & 15.84 & 16.67 & 9-9 & $9-10$ & $12-13$ & 卅 & H \\
\hline 15 & $* * 16.50 ?$ & $* * 12.00 ?$ & $9-9$ & $11-11$ & $16-15$ & H & H \\
\hline
\end{tabular}

* Tail fin excluded. ** Tail segment partly damaged. Maturity condition: - no trace of ovaries or seminal vesicles; + ovaries or seminal vesicles are just appearing; + ovaries or seminal vesicles conspicuous; $\mathrm{H}$ fully matured, ovaries with large ripe eggs; seminal vesicles full or discharging. 

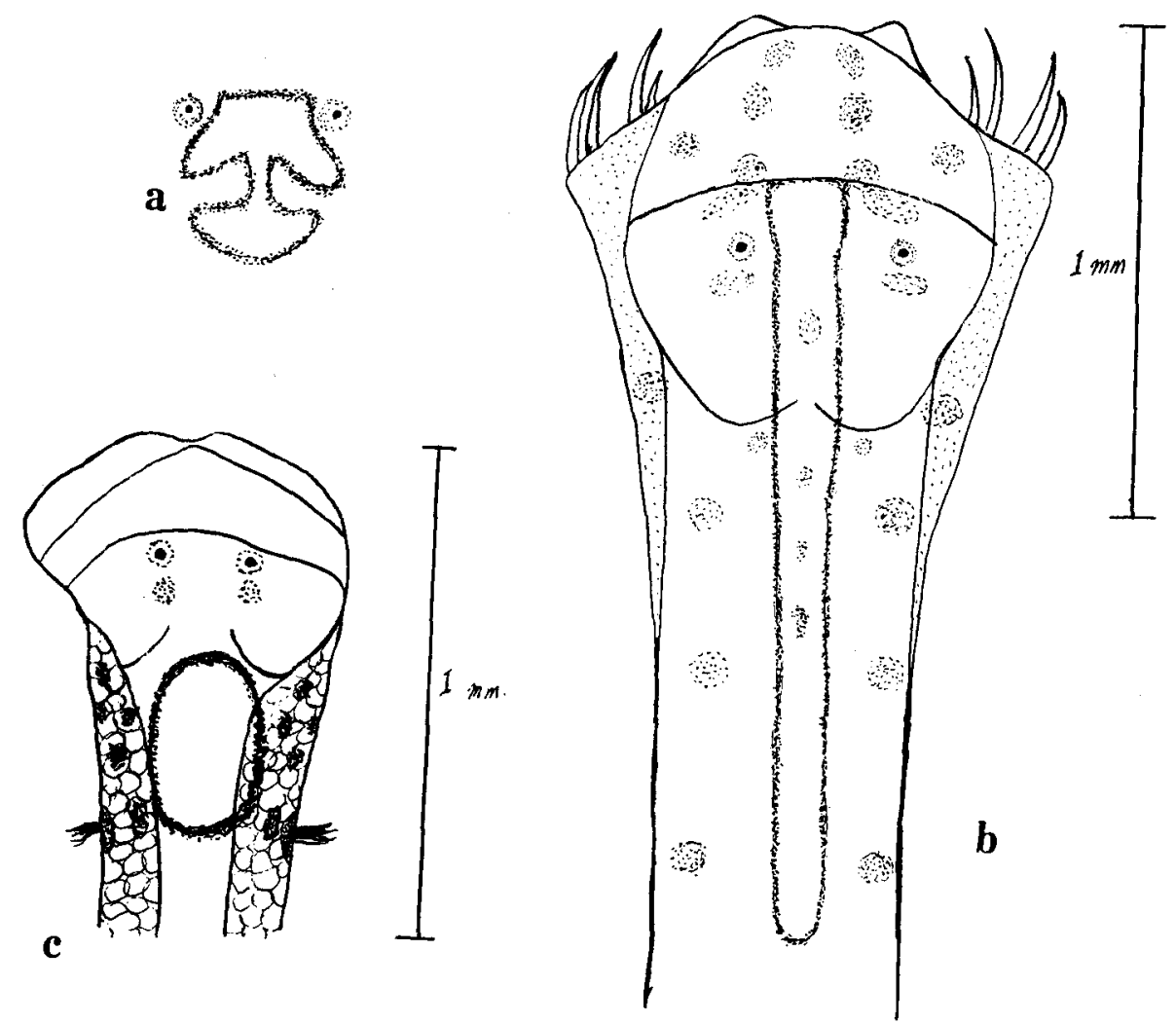

Fig. 5. Corona ciliata of a: Sagitta enflata (13.5 mm long), b: Sagitta bedoti $(11.2 \mathrm{~mm})$, and c: Pterosagitta draco $(4.6 \mathrm{~mm})$.

Table 3. Formulae of Krohnitta pacifica examined.

\begin{tabular}{c|c|c|c|c|c|c}
\hline \hline Sp. No. & $\begin{array}{c}\text { *Body length } \\
\text { in mm }\end{array}$ & $\begin{array}{c}\text { *Tail segment } \\
\text { in \% }\end{array}$ & Hooks & Teeth & Ovaries & $\begin{array}{c}\text { Seminal } \\
\text { vesicles }\end{array}$ \\
\hline 1 & $3 \cdot 30$ & 35.00 & $9-9$ & $7-7$ & - & - \\
2 & 4.62 & 30.36 & $10-10$ & $10-11$ & - & - \\
3 & 4.95 & 36.67 & $10-10$ & $13-13$ & + & + H \\
4 & 5.28 & 34.38 & $10-10$ & $12-12$ & + & + \\
5 & 5.61 & 32.35 & $10-10$ & $13-13$ & + & + \\
6 & 5.61 & 32.35 & $10-10$ & $12-12$ & + & +1 \\
7 & 5.94 & 33.33 & $10-10$ & $12-12$ & H & H \\
\hline
\end{tabular}

* Tail fin excluded. Maturity condition: - no trace of ovaries or seminal vesicles; + ovaries or seminal vesicles are just appearing; \# ovaries or seminal vesicles conspicuous; H seminal vesicles discharging, ovaries with ripe eggs reach $1 / 3$ of the trunk segment. 
estuary.

Figure 6 shows the occurrences and the abundance of $S$. bedoti and $S$. enflata in relation to tidal phases. It is apparent that in the upper estuary the occurrences of

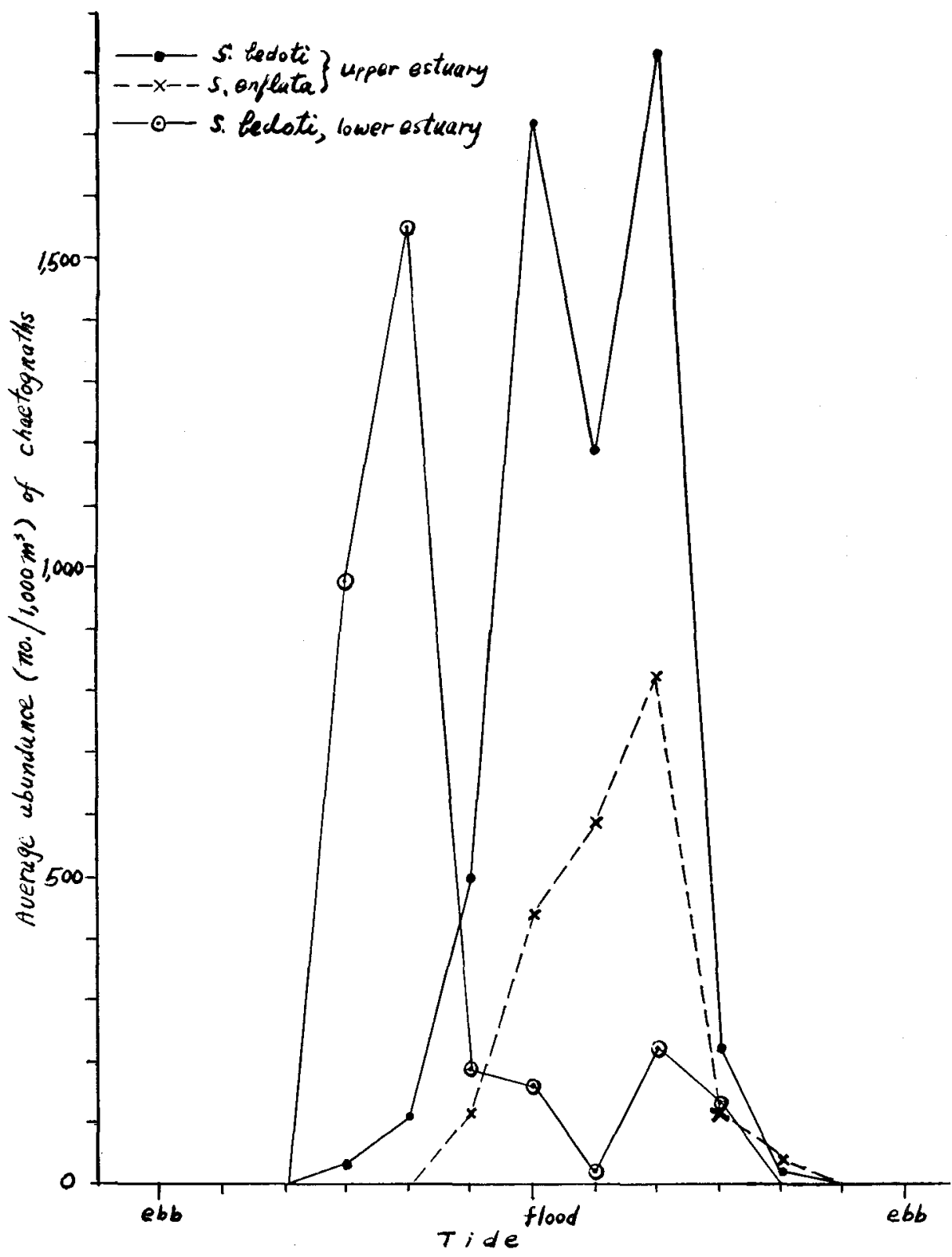

Fig. 6. Relationship between the occurrences and the abundance of chaetognaths and the tidal phases in the Tanshui River Estuary. 
Table 4. Formulae of Pterosagitta draco examined.

\begin{tabular}{c|c|c|c|c|c|c|c}
\hline \hline Sp. No. & $\begin{array}{c}* \text { Body length } \\
\text { in mm }\end{array}$ & $\begin{array}{c}* \text { Tail segment } \\
\text { in \% }\end{array}$ & Hooks & $\begin{array}{c}\text { Anterior } \\
\text { teeth }\end{array}$ & $\begin{array}{c}\text { Posterior } \\
\text { teeth }\end{array}$ & Ovaries & $\begin{array}{c}\text { Seminal } \\
\text { vesicles }\end{array}$ \\
\hline 1 & 4.62 & 35.93 & $10-10$ & $6-6$ & $12-12$ & + & + \\
2 & 4.62 & 35.93 & $8-9$ & $5-5$ & $9-9$ & + & + \\
\hline
\end{tabular}

Table 5. Formulae of Sagitta robusta examined.

\begin{tabular}{c|c|c|c|c|c|c|c}
\hline Sp. No. & $\begin{array}{c}* \text { Body length } \\
\text { in mm }\end{array}$ & $\begin{array}{c}* \text { Tail segment } \\
\text { in \% }\end{array}$ & Hooks & $\begin{array}{c}\text { Anterior } \\
\text { teeth }\end{array}$ & $\begin{array}{c}\text { Posterior } \\
\text { teeth }\end{array}$ & Ovaries & $\begin{array}{c}\text { Seminal } \\
\text { vesicles }\end{array}$ \\
\hline 1 & 5.94 & 29.17 & $7-7$ & $?$ & $10-10$ & H & H \\
2 & 6.60 & 27.50 & $7-7$ & $6-6$ & $13-12$ & H & H \\
\hline
\end{tabular}

Maturity condition: \# seminal vesicles conspicuous; ovaries with round eggs reach $1 / 2$ of the trunk segment.

these chaetognaths were definitely associated with high tide periods. Both species were usually found within three hours before and after the flood tide. However, the curves show that more specimens were collected during and after the highest tide. In lower estuary, on the contrary, more $S$. bedoti were sampled in a few hours before the flood tide.

\section{Abundance of Chaetognaths}

Since the plankton net was mounted with a flow meter, the collections were made roughly quantitatively. In order to compare the abundance of respective species

Table 6. Average abundance $\left(\mathrm{No} / 1,000 \mathrm{~m}^{3}\right)$ of chaetognaths occurred in respective months of observation in the Tanshui River Estuary.

\begin{tabular}{r|r|c|c|c|c}
\hline Month & S. bedoti & S. enflata & S. robusta & K. pacifica & P. draco \\
\hline 1965 Jan. & - & - & - & - & - \\
Feb. & 709.0 & 33.4 & - & 3.3 & - \\
& $* 1137.9$ & $* 11.5$ & - & - & - \\
Aug. & - & - & - & - & - \\
Sept. & 7.8 & - & - & - & - \\
Oct. & 338.4 & 476.9 & - & - & - \\
Nov. & - & - & - & - & - \\
Dec. & 590.8 & 172.9 & - & - & - \\
1966 Feb. & 441.2 & 11.8 & - & - & - \\
& $* 81.0$ & $* 9.7$ & - & - & - \\
Mar. & 1140.4 & 562.2 & - & - & 7.2 \\
Apr. & 5950.1 & 1845.8 & 316.1 & 7.2 & - \\
May & 826.7 & & & - \\
\hline
\end{tabular}

* collected from the lower estuary. 
occurred in each tidal phase and in respective months of observation, numbers of specimens collected in the same tidal phase and in respective months were summed up and compared with the total volume of water filtered by the net. The results are shown in Tables 6 and 7.

Table 7. Average abundance (No./1,000 $\mathrm{m}^{3}$ ) of chaetognaths occurred in the upper estuary (upper figures) and in the lower estuary (lower figures) in different tidal phases.

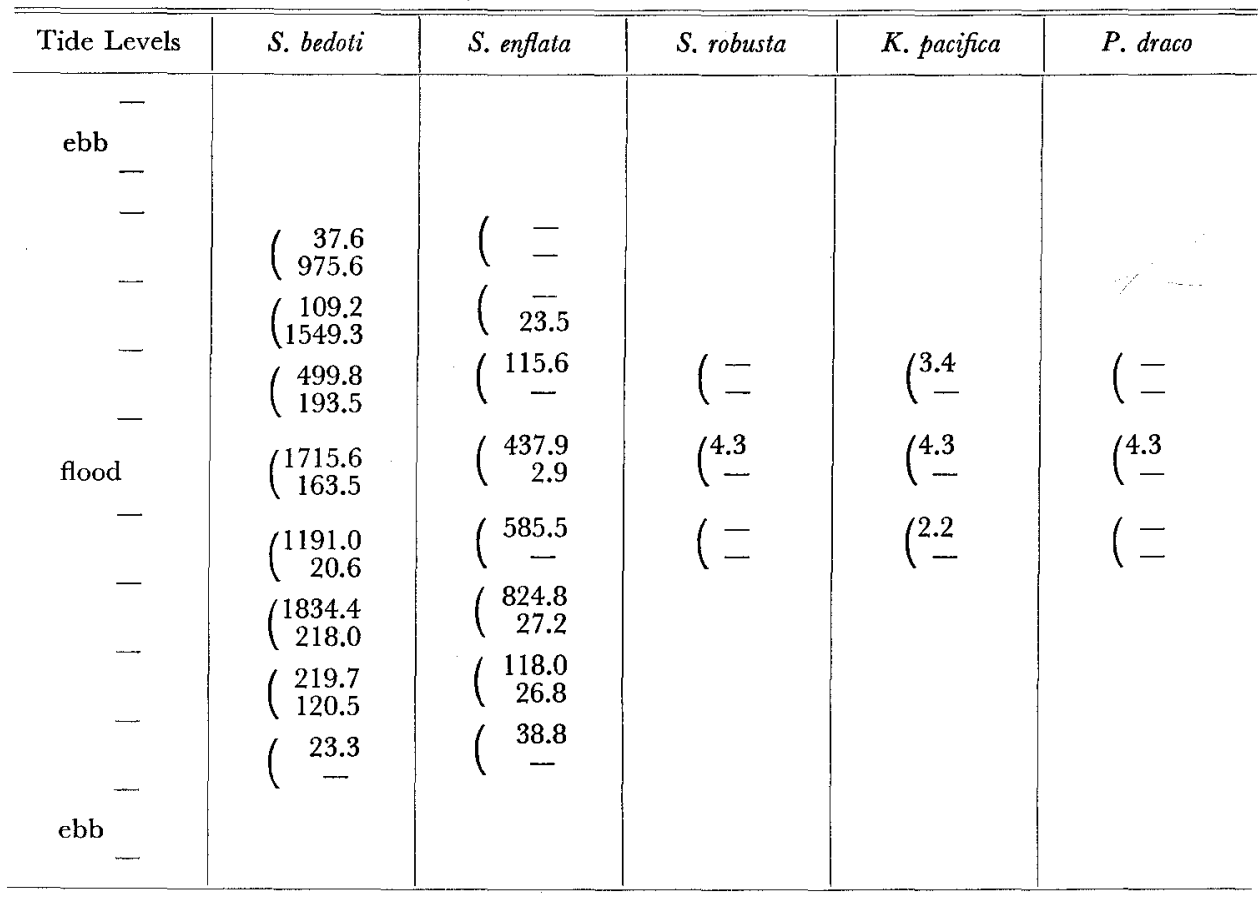

The seasonal fluctuation of the chaetognath population in the estuary does not seem to be very clear from the data presented in Table 6 because of the interruption of observation in January, June and July. However, it may be speculated, on the basis of all available data, that $S$. bedoti probably occurred more abundantly in this estuary during winter and spring months, while $S$. enflata mainly from spring to autumn.

\section{Body Length Distribution of Chaetognaths}

In order to see if there is any difference in the body length of the specimens collected during the flood tide in approximately the same month of three successive years 1964-66, length frequencies of those specimens were plotted against body length as shown in Figure 7. The curves indicate that the modes of the body length distribution are found approximately at $9 \mathrm{~mm}(8.5-9.5 \mathrm{~mm}), 7 \mathrm{~mm}(6.5-7.5 \mathrm{~mm})$ and 


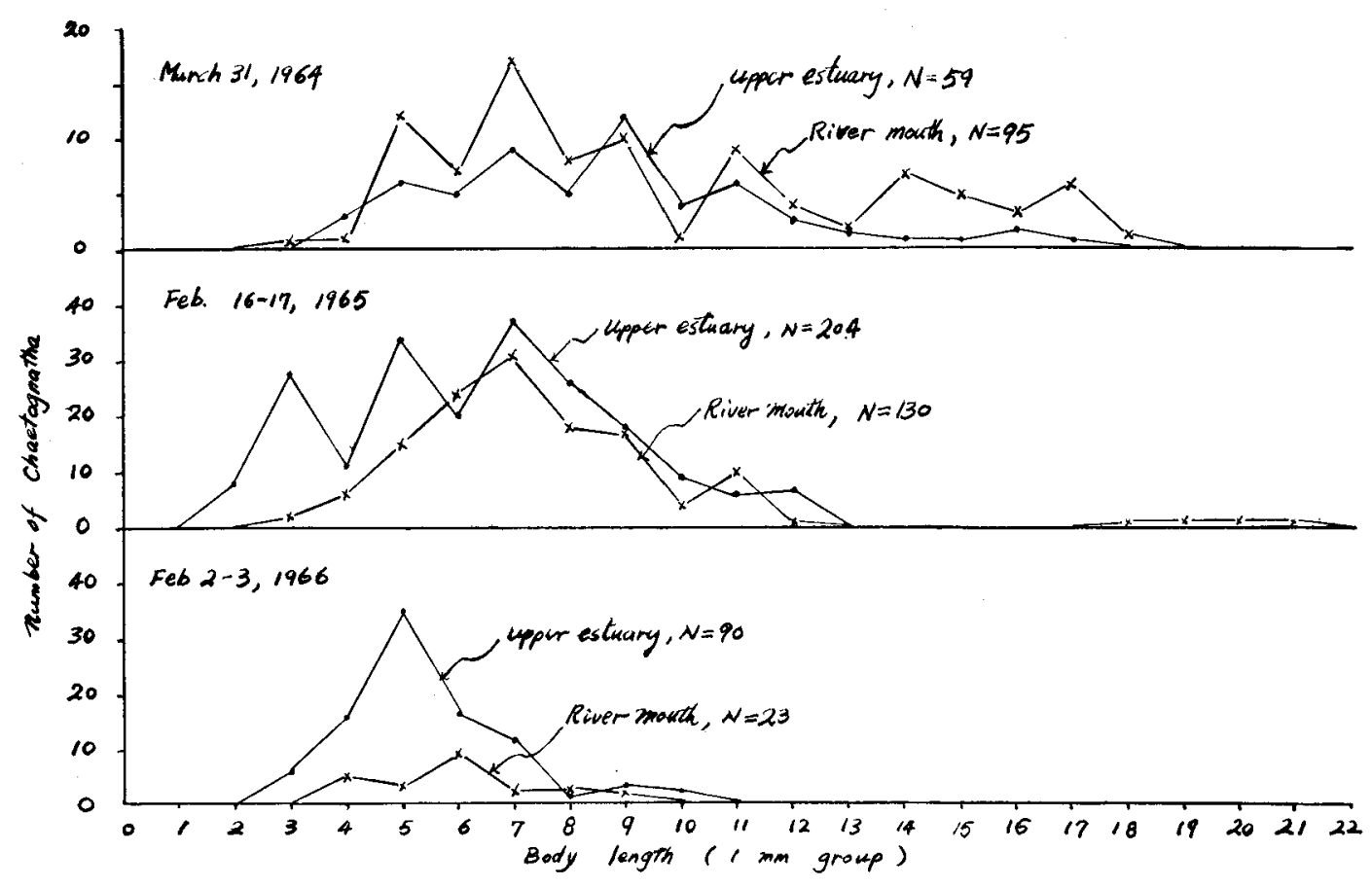

Fig. 7. Length frequencies of S. bedoti from the Tanshui River Estuary in February-March, 1964-66. N, Number of specimens measured.

$5 \mathrm{~mm}(4.5-5.5 \mathrm{~mm})$ for 1964,65 and 66 respectively. No remarkable difference in length distribution is seemingly confirmed between the samples collected from the upper estuary and from the lower estuary.

Body length of specimens collected in different tidal phases on March 4, 1966 were also compared one another (Fig. 8). It was found that both $S$. bedoti and $S$. enflata had their modes of distribution at $5 \mathrm{~mm}(4.5-5.5 \mathrm{~mm})$ during all tidal phases. However, samples collected during the low tide period seemed to have a tendency of having larger $S$. enflata. But the sample size might be too small to judge the validity of this tendency.

Body length of samples taken on May 28-29 in day time and at night from the surface and bottom layers was analysed on comparison (Fig. 9). Although the majority of $S$. bedoti (only a single $S$. enflata was collected at night) were also rather small as in other samples, the proportion of larger specimens seemed to increase at night. No definite difference was found between the surface and bottom samples.

\section{Discussion}

The salinity, temperature, dissolved oxygen, tidal influx and the movement of 


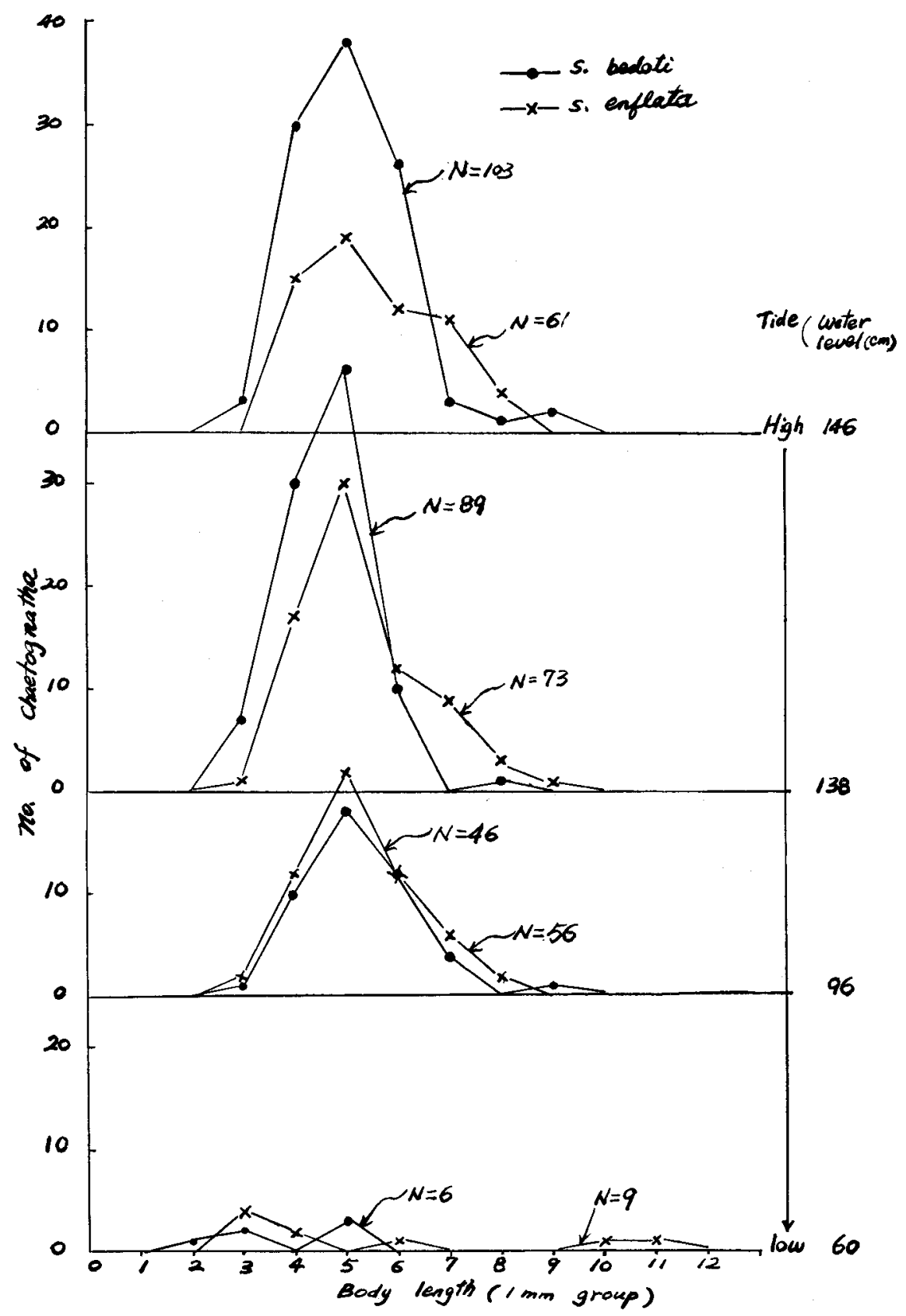

Fig. 8. Length frequencies of chaetognaths from the upper Tanshui River Estuary in different tidal phases. $\mathrm{N}$, Number of specimens measured. 


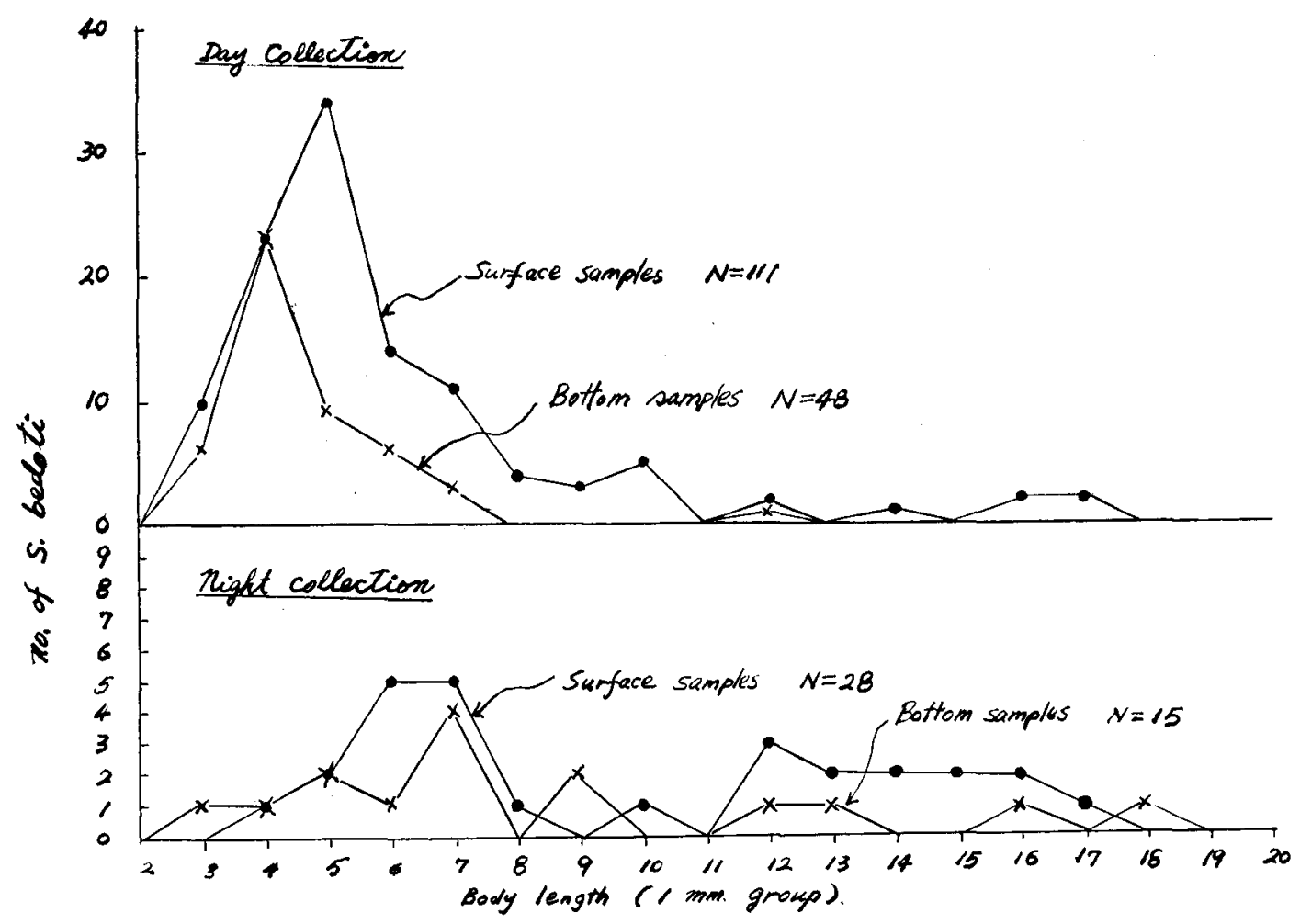

Fig. 9. Length frequencies of $S$. bedoti from the upper Tanshui River Estuary in day time and at night from the surface and bottom layers. N, Number of specimens measured.

the river fresh water are no doubt factors affecting the occurrence and abundance of chaetognaths in this estuary. Although it is hardly possible to find out on the data presented here which of these factors is the most important, it seems probable that the combined effect of daily tidal influx of the sea water and the seaward movement of the river fresh water had more immediate and remarkable influence on the daily occurrence and abundance of the chaetognaths in this area.

BIERI (1959) pointed out that every region of the Pacific has a distinctive chaetognath fauna in relation to different water masses defined by temperaure-salinity relationship, and the chaetognaths in any local fauna are but small parts of large, widespread populations. Therefore, the occurrences of different chaetognath species in this estuary may be taken as reflection of the prevalency of the water masses characterized by those chaetognaths in this coastal region.

$S$. bedoti has been most abundantly found in the temperate $\sim$ tropical near shore waters in the Pacific and has been classified, as a neritic or near shore species (BIERI, 1959; Furuhashi, 1961; Tokroka, 1959). The distribution chart by Bieri (1959) shows that the abundance of $S$. bedoti in the near shore waters of Taiwan was less than 
$50 / 1,000 \mathrm{~m}^{3}$. But, the present study indicates that this species occurred quite abundantly in this estuary. During the high tide period it was estimated as numerous as $1715.6 / 1,000 \mathrm{~m}^{3}$. Therefore, $S$. bedoti is probably indigenous to this area, although its abundance may vary considerably with the seasons. During the period of this study $S$. bedoti was not found in August, and only one specimen was collected in September. Although no collections were made in June and July, it is possible that during these summer months of high water temperature, it did not occur so abundantly as in other months. Besides the water temperature, other factors such as weather condition and rainfall affecting the movement of the river water must be also taken into consideration. The approach of typhoon and the heavy rainfall occurred before or during the observations may have attributed to the complete absence of the chaetognaths in this estuary during this study. The abundant occurrence of $S$. bedoti in the winter season may, however, reflect the influx of the continental neritic water caused by the monsoon from the northwest.

$S$. enflata, $K$. pacifica and $P$. draco have been reported as characteristic species of the oceanic region of the equatorial water mass (BIERI, 1959) and of the Kuroshio (Furuhashi, 1961). Therefore, the invasion of these species into this estuary may be considered as an indication of the coastward movement of such a water mass. The extreme rareness of $K$. pacifica and $P$. draco in this estuary as compared with $S$. enflata is probably due to the fact that these two species occur much less abundantly and far more offshore than S. enflata does (Furuhasm, 1961). Thus, the presence of these rare species may even be a better indication of the inflow of offshore water masses into the nearshore and estuarine waters. The occurrence of a couple of $S$. robusta was probably a contribution from the tropical offshore chaetognath fauna.

The increase of larger individuals in the samples collected at night probably suggests that $S$. bedoti also does the diurnal vertical migration of different scales according to the body size as some other species do (Tokroka, 1940). However, the surface and bottom samples taken in the day time did not differ in length distribution. This is perhaps because the river is too shallow (less than $8 \mathrm{~m}$ deep even in the flood tide in the lower estuary) to allow the invasion of larger individuals staying at the deeper levels of the sea during the day time.

Similarly as in many other plankton animals, most specimens of chaetognaths found in this estuarine region were small and immature; majority of them were in the range of 5-7 $\mathrm{mm}$ in body length. Although this is a very common phenomenon, no satisfactory explanation is still available.

It was suspected that chaetognaths of this estuary might show differentiated salinity tolerance according to species and sizes. The present data, however, do not seem to show any sign in this respect: no difference has been found in length distribution in different saline water or different tidal phases in this estuarine area. 


\section{Acknowledgements}

This investigation was carried out by the grants from the Biological Center, Academia Sinica and from the National Council on Science Development. Thanks are gratefully extended to Dr. Takasi Tokioka of the Seto Marine Biological Laboratory of Kyoto University, Japan for kindly providing the author many of his reprints, confirming the identification of the specimens, and for reading the manuscript.

\section{REFERENGES}

BIERI, R. 1959. The distribution of the planktonic Chaetognatha in the Pacific and their relationship to the water masses. Limnol. Oceanogr., 4 (1): 1-28.

Furuhashi, K. 1961. On the distribution of chaetognaths in the waters off the South-Eastern Coast of Japan. Publ. Seto Mar. Biol. Lab., 9 (1): 17-30.

Ho, J.S. 1963. A preliminary report on chaetognaths collected from Taiwan waters. Rept. Inst. Fish. Biol., Nat. Taiwan Univ., 1 (4) : 21-28.

LEE, C.W. \& GHU, T.Y. 1965. A general survey of Tanshui River and its tributary estuaries. Ibid. $2(1): 34-45$.

Liaw, W.K. 1965. A preliminary survey on the zooplankton of Tanshui River Estuary. Ibid. 2 (1): 27-33.

Pierce, E.L. 1958. The Chaetognatha of the inshore waters of North Carolina. Limnol. Oceanogr., $3(2): 166-170$.

Pierce, E.L. \& Wasss, M.L. 1962. Chaetognatha from the Florida Current and coastal water of the Southeastern Atlantic States. Bull, Mar. Sci., Gulf \& Cari., 12 (3): 403-431.

Sund, P.N. 1959. The distribution of Chatognatha in the Gulf of Alaska in 1954 and 1956. J. Fish. Res. Bd., Canada. 16 (3): 351-361.

Токюка, T. 1940. Phylum Chaetognatha. Fauna Nipponica, Vol. V, No. II (in Japanese). 1959. Observations on the taxonomy and distribution of chaetognaths of the North Pacific. Publ. Seto Mar. Biol. Lab., 7 (3): 57-164.

__ 1965. The taxonomical outline of Chaetognatha. Ibid. 7 (5): 335-357.

-1965. Supplementary notes on the systematics of Chaetognatha. Ibid. 8 (3): 231-242.

\section{EXPLANATION OF PLATE I.}

Seminal vesicles of chaetognaths from the Tanshui River Estuary.

Fig. 1. Sagitta bedoti, $17.2 \mathrm{~mm}$ long, ventral.

Fig. 2. Sagitta bedoti, $17.8 \mathrm{~mm}$ long, ventral, discharged.

Fig. 3. Sagitta enflata, $16.2 \mathrm{~mm}$ long, ventral.

Fig. 4. Krohnitta pacifica, $5.7 \mathrm{~mm}$ long, ventral. 
Publ. Seto Mar. Biol. Lab., XV (1), 1967.

PTATE I

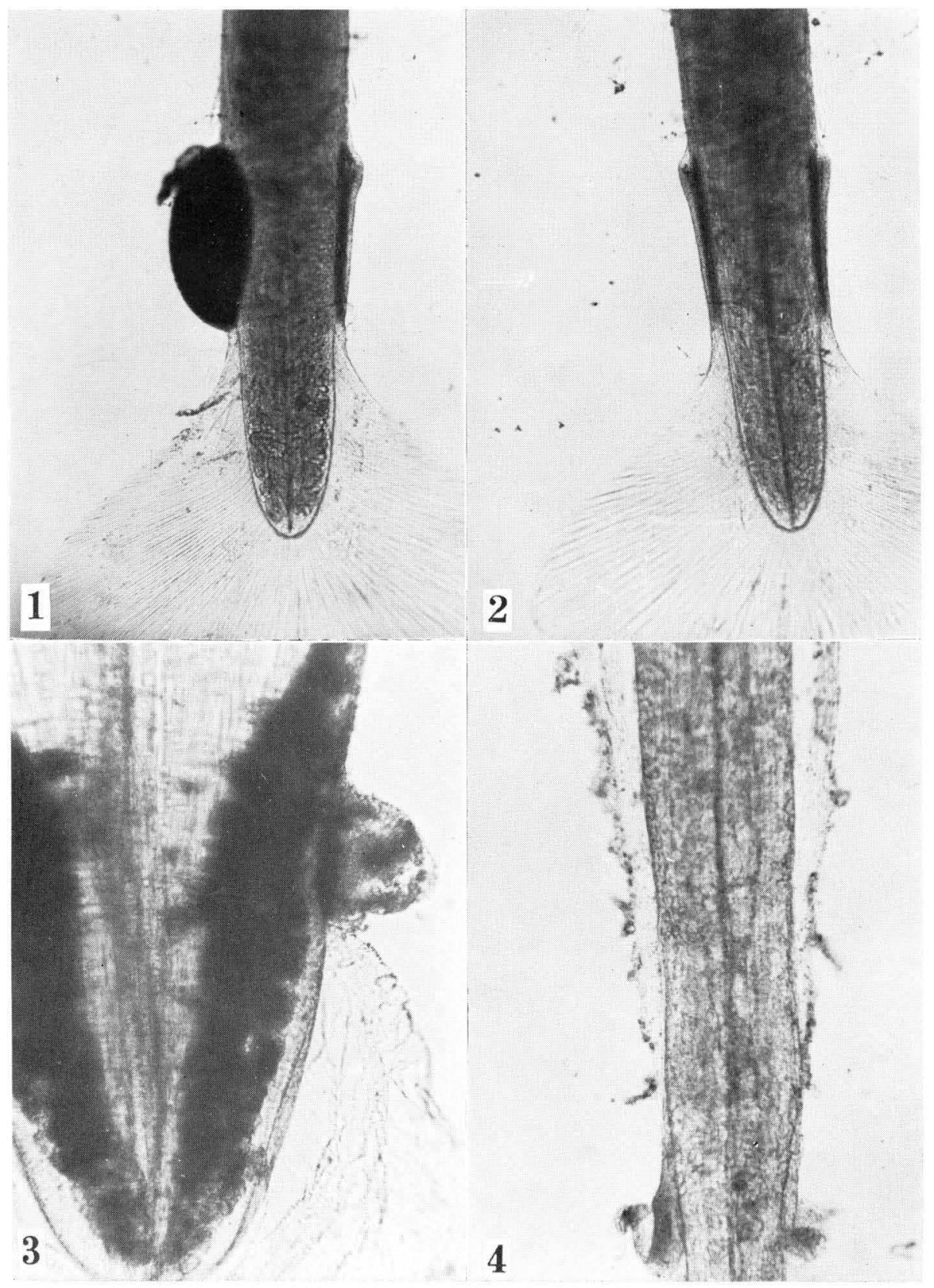

W. K. Liaw: Chaetognaths in Tanshui River Estuary 